\title{
RADIAL VARIATION IN CELL MORPHOLOGY OF Melia azedarach PLANTED IN NORTHERN VIETNAM
}

\author{
Doan Van Duong ${ }^{1, \star}$ \\ https://orcid.org/0000-0001-8904-0989 \\ Laurence Schimleck ${ }^{2}$ \\ Tai Tien Dinh \\ Chu Van Tran ${ }^{4}$
}

\begin{abstract}
The radial variation in cell morphology of ten-year-old Melia azedarach trees planted in northern Vietnam was experimentally investigated. The earlywood fiber lumen diameter and latewood fiber lumen diameter were almost unchanged from pith to 6th ring before significantly decreasing and remaining constant from 7 th ring outwards. In contrast, fiber cell wall thickness in both earlywood and latewood increased from pith to 7th ring before becoming stable towards the bark. The maturation age of earlywood vessel lumen diameter estimated by segmented regression analysis indicated that wood of the Melia azedarach could be classified into core wood and outer wood, and the boundary between core and outer wood may be located at 7 th ring from pith. This should be taken into account in wood processing using M. azedarach grown in northern Vietnam.
\end{abstract}

Keywords: Cell wall thickness, core wood, earlywood, latewood, outer wood, specific gravity, vessel lumen diameter.

\section{INTRODUCTION}

Melia azedarach belongs to the Meliaceae family which produces many well-known timber trees such as Swietenia macrophylla King and Cedrela odorata L. in South America and Africa; and Entandrophragma utile (Dawe \& Sprague) Sprague and Entandrophragma cylindricum Harms in tropical Africa. M. azedarach is native to northern Australia and Himalaya region of Asia, and is now naturalized in most subtropical and tropical regions of the world (Venson et al. 2008, Duong et al. 2017). Its wood has been used for manufacturing agricultural implements, furniture, plywood, boxes, poles, tool handles, and light weight construction materials (Harrison et al. 2003, El-Juhany 2011). Currently, decreasing wood resources from native forests and the increase in wood processing costs have led to significant interest in wood sourced from plantations. Owing to the value of wood from other members of the Meliaceae, M. azedarach has recently received considerable attention given its relatively fine grain, durability, resistance to termites and insects, and ease of working (Duong 2018). In addition, with other fast-growing species, M. azedarach could contribute to the prevention of global warming owing to the ability to rapidly store carbon (Osei et al. 2018). M. azedarach, has become an important plantation species in Vietnam; however, further research is needed for effective utilization of wood from this species, such as the production of structural lumber.

\footnotetext{
${ }^{1}$ Thai Nguyen University of Agriculture and Forestry, Faculty of Forestry, Thai Nguyen, Vietnam.

${ }^{2}$ Oregon State University, Wood Science and Engineering, Corvallis, OR, USA.

${ }^{3}$ Hue University, Institute of Resources and Environment, Hue, Vietnam.

${ }^{4}$ Vietnam Forestry University, Faculty of Wood Technology, Ha Noi, Vietnam.

"Corresponding author: duongvandoan@tuaf.edu.vn

Received: 10.12.2019 Accepted: 08.09.2020
} 
There are some reports on $M$. azedarach wood properties with general agreement that wood of $M$. azedarach has a medium specific gravity (SG) (El-Juhany 2011, Trianoski et al. 2011, Duong et al. 2017) and medium dimensional stability (Venson et al. 2008, Duong and Matsumura 2018a). Mechanical properties of $M$. azedarach wood were also reported by some researchers (Matsumura et al. 2006, Venson et al. 2008, Duong and Matsumura 2018b, Duong et al. 2019) who suggested the possibility of using wood of M. azedarach as a new timber source. Within-tree variation of M. azedarach physical (Duong and Matsumura 2018a) and mechanical wood properties (Duong and Matsumura 2018b) have also been examined, and it was observed that wood beyond ring 7 from the pith displayed mature wood properties, i.e. comparatively long fibers, high specific gravity, and low microfibril angle (MFA) in the $\mathrm{S}_{2}$ layer of the cell wall (Duong et al. 2017).

There are few published studies on the wood anatomy of M. azedarach (Lev-Yadun and Aloni 1993, Duong et al. 2017) and information on wood variability related to anatomical patterns of variation, which may have a large influence on processing and product performance (Walker 2006), is lacking. Further, no information regarding wood anatomical variation in relation to juvenile and mature wood or identification of when the transition occurs is available. Hence to better understand anatomical characteristics of $M$. azedarach, this study examined radial variation in cell morphology for plantation grown trees from northern Vietnam. Based on the results obtained, the process of xylem maturation, and the relationship between anatomical characteristics and wood properties are discussed.

\section{MATERIALS AND METHODS}

\section{Sample preparation}

Ten-year-old Melia azedarach L. trees were sampled from a state-owned plantation in Thai Binh province, Vietnam $\left(20^{\circ} 38^{\prime} 33^{\prime \prime} \mathrm{N}, 106^{\circ} 12^{\prime} 16^{\prime \prime} \mathrm{E}\right)$. As seedlings, the trees were planted at a spacing of $4 \mathrm{~m} \times 3 \mathrm{~m}$. Three trees were chosen for destructive sampling based on straightness, normal branching, and absence of any disease or pest symptoms (Table 1). The north and south sides of the sample trees were marked before felling. A cross-sectional disc $30 \mathrm{~mm}$ thick was cut from each sample tree at a height 1,3 $\mathrm{m}$ above the ground. From each disc, pith-to-bark strips (Radius $\times 10$ (Tangential) $\times 10($ Longitudinal) $\mathrm{mm}$ ) and (Radius $\times 30(\mathrm{~T}) \times 15(\mathrm{~L}) \mathrm{mm})$ were cut from the south side to examine cell morphology and wood SG, respectively. All strips were conditioned (temperature $20{ }^{\circ} \mathrm{C}$ and relative humidity $60 \%$ ) to a constant weight before commencing experiments.

Table 1: Diameter and height of the sampled trees.

\begin{tabular}{|c|c|c|}
\hline Tree no. & DBH (cm) & H (m) \\
\hline 1 & 30,0 & 15,6 \\
\hline 2 & 25,2 & 14,5 \\
\hline 3 & 22,8 & 16,3 \\
\hline
\end{tabular}

Note: $\mathrm{DBH}$, diameter at breast height (at 1,3 $\mathrm{m}$ above the ground); $\mathrm{H}$, tree height.

\section{Cell morphology}

Radial variation of cell morphology was investigated by the method described by Ishiguri et al. (2012). Transverse sections ( $20 \mu \mathrm{m}$ in thickness) were obtained from each ring with a sliding microtome. The sections were stained with safranin and then dehydrated and mounted in biolite (Wako Pure Chemical Industries, Ltd.). Digital images of transverse sections were taken using a digital camera (CAMEDIA C5050ZOOM, Olympus) attached to an optical microscope and analyzed with ImageJ software (National Institute of Heath 2012). For each ring earlywood vessel lumen diameter (EVLD), earlywood fiber lumen diameter (EFLD), and earlywood fiber cell wall thickness (ECWT) were measured on the first 5 rows of earlywood cells, while latewood vessel lumen diameter (LVLD), latewood fiber lumen diameter (LFLD), and latewood fiber cell wall thickness (LCWT) were measured on the outermost latewood cells. Average tangential and radial lumen diameters were determined by measuring 30 vessels and fibers in each ring. Double wall thickness of 30 fiber cells was measured, and one half of the double wall thickness was defined as the fiber wall thickness in each ring. Average tangential and radial fiber diameter was determined by summing average lumen diameter and wall thickness $(\times 2)$. 


\section{Specific gravity}

Specific gravity (SG) was measured as described by Duong et al. (2017). Due to distinct growth rings, radial strips were then cut into individual rings for measurement of SG in air-dry condition. SG was measured by an electronic densimeter MD-300S. Measurement time per sample was about 10 seconds. All experiments in this study were conducted at Kyushu University Wood Science Laboratory, Japan.

\section{Maturation age estimation}

We observed that the changes in EVLD with increasing cambial age followed a nonlinear pattern with an upper asymptote. Thus, a segmented regression model with quadratic equation and a plateau (Equation 1 and Equation 2) was adopted to describe this relationship (Tsuchiya and Furukawa 2009b) as follows:

$$
\begin{array}{ll}
y=\beta_{0}+\beta_{1} \mathrm{x}+\beta_{2} \mathrm{x}^{2} & \text { if } x<M(1) \\
y=P & \text { if } x \geq M(2)
\end{array}
$$

In which, $x$ is cambial age; $y$ is earlywood vessel lumen diameter (EVLD); $M$ is maturation age; $P$ is a plateau; $\beta_{0}$ is the intercept, and $\beta_{1}$ and $\beta_{2}$ are the first and the second coefficient estimates for the quadratic segment of the model, respectively.

The parameters $\left(\beta_{0}, \beta_{1}\right.$ and $\left.\beta_{2}\right)$ were estimated using nonlinear least-squares function $(n l s)$ in $\mathrm{R}$ version 3.3.2 (R Core Team 2016). The maturation age $(M)$ and a plateau $(P)$ of EVLD were then calculated from coefficient estimates of the quadratic segment in the model as follows (Equation 3 and Equation 4):

$$
\begin{aligned}
& M=\frac{-\beta_{1}}{2 \beta_{2}} \\
& P=\beta_{0}-\frac{\beta_{1}^{2}}{4 \beta_{2}}
\end{aligned}
$$

\section{RESULTS AND DISCUSSION}

\section{Radial variation in cell morphology}

Descriptive statistics (means and standard deviations) in cell morphology and SG of the sampled M. azedarach trees planted in northern Vietnam are shown in Table 2. Average EVLD was 137,79 $\mu \mathrm{m}$ varying between trees from $133,67 \mu \mathrm{m}$ to $144,96 \mu \mathrm{m}$; and average LVLD was $90,37 \mu \mathrm{m}$ varying from $82,83 \mu \mathrm{m}$ to 94,52 $\mu \mathrm{m}$. Lumen diameter of earlywood fibers averaged 7,15 $\mu \mathrm{m}$ (range $6,93 \mu \mathrm{m}$ to 7,35 $\mu \mathrm{m}$ ) and 4,38 $\mu \mathrm{m}$ (range $4,15 \mu \mathrm{m}$ to $4,73 \mu \mathrm{m}$ ) in latewood, while fiber wall thickness varied from $1,04 \mu \mathrm{m}$ to $1,08 \mu \mathrm{m}$ in earlywood and from 1,74 $\mu \mathrm{m}$ to 1,79 $\mu \mathrm{m}$ in latewood (Table 2). Palakit et al. (2018) reported vessel diameters for M. azedarach grown in northeastern Thailand that ranged from $120 \mu \mathrm{m}$ to $210 \mu \mathrm{m}$ but to the best of our knowledge, there have been no previous reports of lumen diameters of fibers, and fiber wall thickness. Thus, the present study experimentally documents these properties of M. azedarach for the first time. Anoop et al. (2014) reported the anatomical properties of S. macrophylla, and showed that the values of vessel diameter in earlywood, fiber lumen diameter and fiber wall thickness were $167,6 \mu \mathrm{m}, 12,8 \mu \mathrm{m}$, and 1,9 $\mu \mathrm{m}$, respectively, which are similar to what we report for M. azedarach.

The overall value of wood SG was 0,52 varying between trees from 0,51 to 0,54 and this finding is in agreement with our previous work (Duong et al. 2017), in which we showed that wood SG values of 17 to 19-year-old M. azedarach planted in northern Vietnam ranged from 0,52 to 0,57 between trees. Other studies have shown that M. azedarach SG varies considerably. For example, for 17-year-old M. azedarach grown in Japan, Matsumura et al. (2006) found that SG ranged from 0,43 to 0,52 while Bolza and Kloot (1963) report 
a density of $445 \mathrm{~kg} / \mathrm{m}^{3}$ for $M$. azedarach var australasica (age was not specified for the sampled trees). Later studies by Nasser (2008) and Nasser et al. (2010) examined wood properties of 9-year-old M. azedarach grown in Egypt and Saudi Arabia respectively. SG's of trees irrigated with sewage effluent in Egypt $(0,60)$ and primary treated sewage-effluent in Saudi Arabia $(0,65)$ were higher than those of trees irrigated with municipal water (0,55 and 0,59 respectively). The higher SG's reported by Nasser (2008) and Nasser et al. (2010) can likely be explained by the use of irrigation in these studies which reduced water stress permitting an extended period of latewood production.

Table 2: Characteristics of cell morphology and wood property in the sample Melia azedarach trees.

\begin{tabular}{|l|c|c|c|r|r|r|r|r|r|}
\hline \multirow{2}{*}{ Property } & \multirow{2}{*}{$\mathrm{n}$} & \multicolumn{2}{|c|}{ Tree } & \multicolumn{2}{c}{ Tree 2 } & \multicolumn{2}{c|}{ Tree 3 } & \multicolumn{2}{c|}{ Total } \\
\cline { 3 - 10 } & Mean & \multicolumn{1}{c|}{ SD } & Mean & \multicolumn{1}{c|}{ SD } & Mean & SD & Mean & SD \\
\hline Cell morphology & & & & & & & & & \\
\hline $\begin{array}{l}\text { Earlywood vessel } \\
\text { lumen diameter }(\mu \mathrm{m})\end{array}$ & 10 & 133,67 & 31,81 & 134,72 & 34,61 & 144,96 & 36,70 & 137,79 & 33,41 \\
\hline $\begin{array}{l}\text { Latewood vessel } \\
\text { lumen diameter }(\mu \mathrm{m})\end{array}$ & 10 & 92,54 & 17,73 & 82,83 & 14,42 & 94,52 & 20,00 & 90,37 & 18,25 \\
\hline $\begin{array}{l}\text { Earlywood fiber } \\
\text { lumen diameter }(\mu \mathrm{m})\end{array}$ & 10 & 7,17 & 1,34 & 7,35 & 1,21 & 6,93 & 1,54 & 7,15 & 1,38 \\
\hline $\begin{array}{l}\text { Latewood fiber lumen } \\
\text { diameter }(\mu \mathrm{m})\end{array}$ & 10 & 4,73 & 1,14 & 4,26 & 0,86 & 4,15 & 0,81 & 4,38 & 0,95 \\
\hline $\begin{array}{l}\text { Earlywood fiber cell } \\
\text { wall thickness }(\mu \mathrm{m})\end{array}$ & 10 & 1,07 & 0,20 & 1,04 & 0,21 & 1,08 & 0,22 & 1,06 & 0,21 \\
\hline $\begin{array}{l}\text { Latewood fiber cell } \\
\text { wall thickness }(\mu \mathrm{m})\end{array}$ & 10 & 1,74 & 0,29 & 1,79 & 0,31 & 1,74 & 0,39 & 1,76 & 0,34 \\
\hline Wood property & & & & & & & & & \\
\hline Specific gravity & 10 & 0,51 & 0,06 & 0,54 & 0,06 & 0,52 & 0,06 & 0,52 & 0,06 \\
\hline
\end{tabular}

Note: n, number of rings; SD, standard deviation.

Images showing variation in vessels and fibers for rings of different ages are shown in Figure 1 and Figure 2 respectively, while radial patterns of variation in cell morphology from pith to bark in earlywood and latewood of M. azedarach planted in northern Vietnam are shown in Figure 3. Vessel lumen diameter of $M$. azedarach trees tended to rapidly increase up to 7 th ring from the pith before becoming constant towards the bark both in earlywood and latewood (Figure 3a and Figure 3b). The EFLD and LFLD, on the contrary, showed increasing and decreasing trends respectively from pith to 6th ring before significantly decreasing and then remaining constant from 7 th ring outwards (Figure $3 \mathrm{c}$ and Figure 3d). The radial pattern in ECWT and LCWT was similar to that of the vessel lumen diameter (Figure 3e and Figure 3f). The radial pattern of variation from pith to periphery of these anatomical properties has been reported for other ring-porous species. For M. dubia (up to age 5) observed trends for vessel diameter and fiber wall thickness were consistent with our findings, while fiber lumen width decreased $(15,9 \mu \mathrm{m}$ to $9,4 \mu \mathrm{m}$ ) (Saravanan et al. 2013). It should be noted that Saravanan et al. (2013) did not distinguish between earlywood and latewood, if our earlywood and latewood observations for fiber lumen width were averaged then a similar trend would be observed. In S. macrophylla, Anoop et al. (2014) indicated that the vessel diameter gradually increased from pith to bark, while fiber wall thickness increased from pith to a peak, and declined towards the periphery in the radial direction. Tsuchiya and Furukawa (2009b) found that vessel lumen diameter in earlywood increased in size for up to 20 years before stabilizing in the ring-porous hardwoods Acanthopanax sciadophylloides and Evodiopanax innovans. 

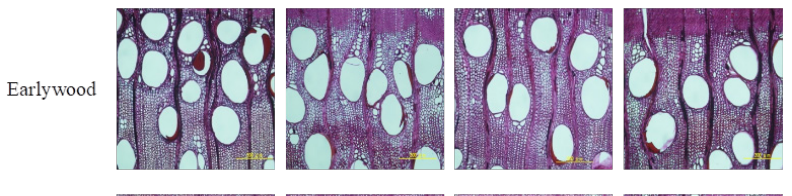

Latewood

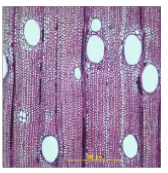

3 th ring

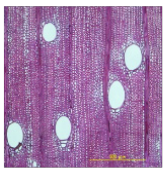

6th ring

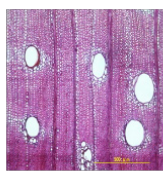

7 th ring

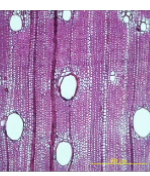

8th ring

Figure 1: Images of vessels in different growth rings from pith of Melia azedarach (tree number 1).

Scale bar $=500 \mu \mathrm{m}$.

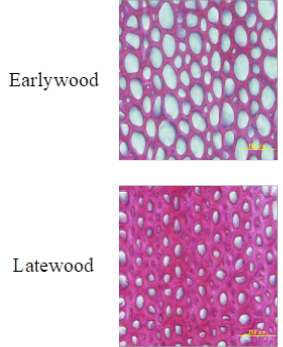

3 th ring
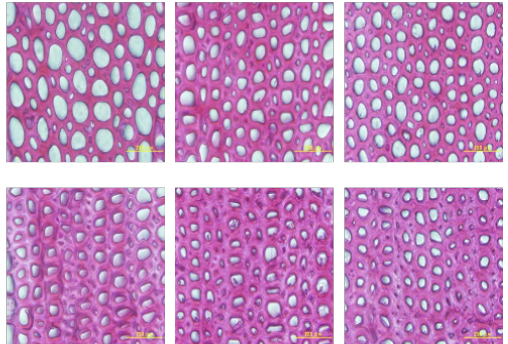

6th ring

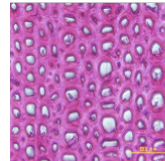

7 th ring

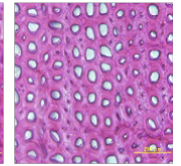

8th ring

Figure 2: Images of wood fibers in different growth rings from pith of Melia azedarach (tree number 3).

Scale bar $=200 \mu \mathrm{m}$

Various wood anatomical properties can be used to differentiate between juvenile and mature wood (Bhat et al. 2001, Tsuchiya and Furukawa 2009b). Juvenile wood is formed by young cambium in which anatomical structure such as cell length and cell width changes rapidly with cambial age, while mature wood is formed when length of fusiform cambial cells becomes more or less constant or increases much more slowly with cambial age (Tsuchiya and Furukawa 2009a). In hardwoods, vessel elements in diffuse-porous wood and earlywood vessel elements in ring-porous wood have approximately the same length as the fusiform cambial cells from which they are derived, and wood fibers constitute the dominant component (Kitin et al. 1999, Tsuchiya and Furukawa 2009a). Radial variations of various anatomical properties, especially wood fiber length, vessel element length and vessel lumen diameter have been frequently considered for age demarcation between juvenile and mature wood (Lei et al. 1996, Gartner et al. 1997, Bhat et al. 2001, Honjo et al. 2005, Tsuchiya and Furukawa 2009a and Tsuchiya and Furukawa 2009b).

EVLD is one of the properties used to differentiate between juvenile and mature wood. EVLD generally shows an increase from pith to the bark, where EVLD is smaller near the pith, and gradually increases in size radially before leveling off in the outer part of the stem (Bhat et al. 2001, Tsuchiya and Furukawa 2009a, Tsuchiya and Furukawa 2009b) and as observed in Figure 3a and Figure 3b. To estimate EVLD maturation age in $M$. azedarach we used a segmented regression model with quadratic equation and a plateau. We found that EVLDs increased rapidly in the inner part of the stem, and these values tended to be unchanged with an estimated plateau of $156 \mu \mathrm{m}$ from cambial age of 7,4 towards the periphery of the tree (Figure 4). The obtained result is comparable with those reported by Duong et al. (2017) showing that wood of M. azedarach beyond ring number 7 from pith had comparatively long fibers, high SG, and low MFA in the $\mathrm{S}_{2}$ layer of fiber cell walls. These findings suggest that wood of the $M$. azedarach could be classified into core wood and outer wood based on EVLD, and the boundary between core and outer wood may be located at 7th ring from pith. This should be taken into account in wood processing using M. azedarach grown in northern Vietnam. In other studies of plantation grown $M$. azedarach higher stocking rates have been employed, for example $2 \mathrm{~m} \times 2 \mathrm{~m}$ in Nasser et al. (2010) and spacing's ranging from $1 \mathrm{~m} \times 1 \mathrm{~m}$ to $3 \mathrm{~m} \times 2 \mathrm{~m}$ in Leles et al. (2014). The influence of different planting densities on the maturation of $M$. azedarach is unknown and requires further investigation. 

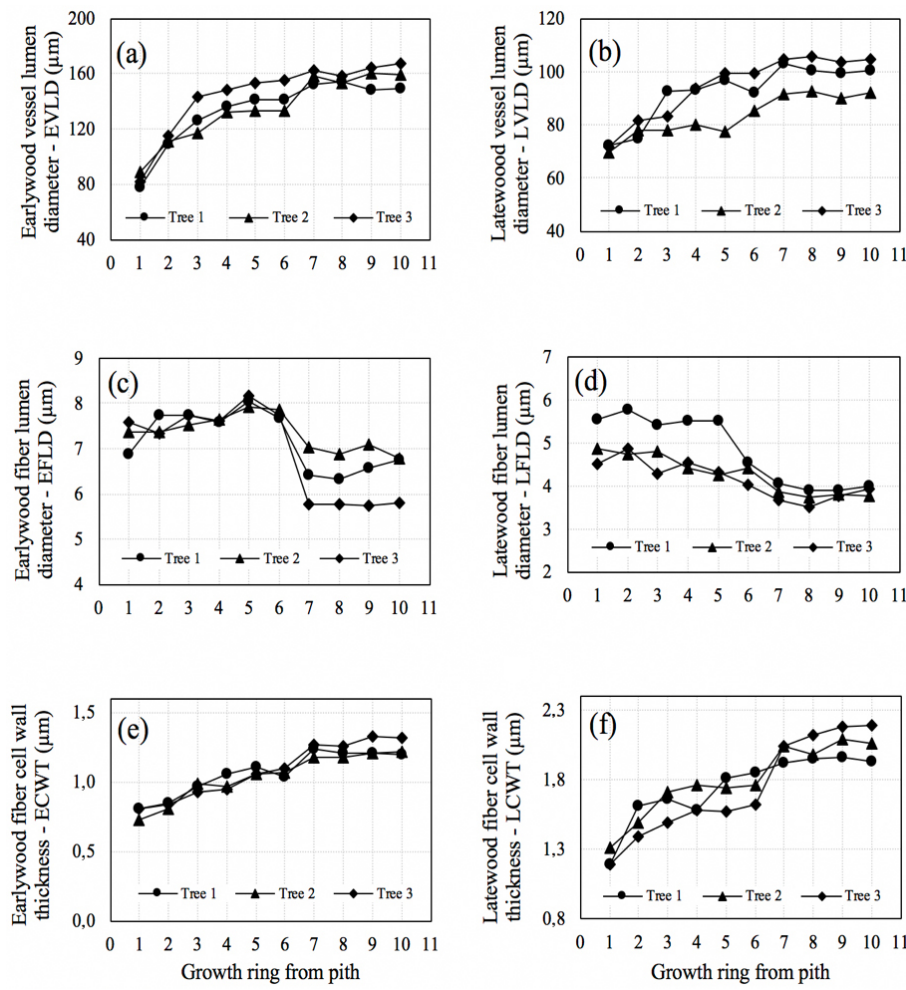

Figure 3: Radial variation in cell morphology from pith to bark in earlywood and latewood of Melia azedarach planted in northern Vietnam.

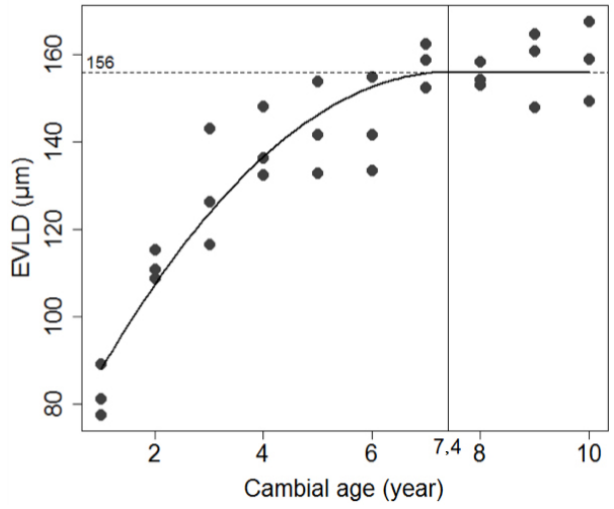

Figure 4: Changes in EVLD with increasing cambial age in Melia azedarach planted in Vietnam. A quadratic model with a plateau was fitted to show the maturation age. Coefficient estimates of the quadratic model, $\beta_{0}$, $\beta_{1}$ and $\beta_{2}$, are 65,$20 ; 24,39$ and 1,64 respectively. Points showed observed values in sample trees.

\section{Relationship between anatomical characteristics and wood density}

It has been shown by many investigators that wood properties are closely related to anatomical structure, and a detailed analysis of wood structure has been considered necessary to sufficiently explain wood property variation (Ifju 1983, Zhang and Zhong 1992). Wood density is a key indicator of wood quality because it is 
closely correlated with many physical and technological properties (Miranda et al. 2001). The density of wood depends on the size of cells, the thickness of the cell walls, and the interrelationship between the two features (Panshin and DeZeeuw 1980, Ishiguri et al. 2012). Assuming a constant cell wall density, wood density will be mainly determined by the voids in the wood mass, i.e., by the size of lumens in the wood cells (predominantly fibers and vessels in hardwoods). The size and density of vessels therefore have a major effect on wood density and tend to be inversely proportional to this property (Savidge 2003). In this study, as shown in Table 3, a significant positive correlation was found between vessel lumen diameter and SG both in early and latewood (Pearson's correlation coefficient $r=0,79$ in earlywood, $r=0,62$ in latewood). While contradictory to those reported by Savidge (2003) a positive correlation between vessel lumen diameter and wood density was also found in Casuarina equisetifolia (Chowdhury et al. 2012). A probable explanation is that average vessel lumen diameter increased, while vessel frequency decreased from the pith to bark. Further experiments related to variation in vessel area of $M$. azedarach in radial direction will clarify the relation of wood density with vessel lumen diameter. There was a significantly positive relationship between wood fiber cell wall thickness and SG $(r=0,78$ in earlywood, $r=0,79$ in latewood) while wood fiber lumen diameter was negatively correlated with SG. The present results are in line with those of Ishiguri et al. (2009) and Chowdhury et al. (2012) for Paraserianthes falcataria and C. equisetifolia, respectively.

Table 3: Pearson's correlation coefficients between anatomical characteristics and wood specific gravity in Melia azedarach.

\begin{tabular}{|l|c|}
\hline Anatomical characteristics & Specific gravity \\
\hline Earlywood vessel lumen diameter $(\mu \mathrm{m})$ & $0,79^{* * *}$ \\
\hline Latewood vessel lumen diameter $(\mu \mathrm{m})$ & $0,62^{* * *}$ \\
\hline Earlywood fiber lumen diameter $(\mu \mathrm{m})$ & $-0,28^{\text {ns }}$ \\
\hline Latewood fiber lumen diameter $(\mu \mathrm{m})$ & $-0,64^{* * *}$ \\
\hline $\begin{array}{l}\text { Earlywood fiber cell wall thickness } \\
(\mu \mathrm{m})\end{array}$ & $0,78^{* * *}$ \\
\hline Latewood fiber cell wall thickness $(\mu \mathrm{m})$ & $0,79^{* * *}$ \\
\hline
\end{tabular}

**** $p$-value $<0,001 ;$ ns: not significant.

\section{CONCLUSIONS}

We investigated the radial variations in cell morphology and wood property of ten-year-old M. azedarach planted in northern Vietnam. Our results indicated that the vessel lumen diameter of the M. azedarach trees rapidly increased up to 7 th ring from the pith before becoming constant towards the bark both in earlywood and latewood. EFLD and LFLD showed similar values from pith to 6th ring; however, EFLD and LFLD demonstrated increasing and decreasing trends respectively, before significantly decreasing and remaining constant from 7th ring outwards. ECWT and LCWT increased gradually with cambial age up to 7th ring before being less or more stable to the bark. Our data provide evidence that wood of the M. azedarach could be classified into core wood and outer wood based on EVLD, and the boundary between core and outer wood may be located at 7th ring from pith. Significant correlation coefficients were found between anatomical characteristics and SG except for EFLD and SG.

\section{ACKNOWLEDGMENTS}

The authors express sincere thanks to Professor Junji Matsumura, Faculty of Agriculture, Kyushu University, Japan for providing space and facilities to support our work. 


\section{REFERENCES}

Anoop, E.V.; Jijeesh, C.M.; Sindhumathi, C.R.; Jayasree, C.E. 2014. Wood physical, anatomical and mechanical properties of big leaf Mahogany (Swietenia macrophylla Roxb) a potential exotic for South India. Research Journal of Agriculture and Forestry Sciences 2(8): 7-13. http://www.isca.me/AGRI FORESTRY/Archive/v2/i8/2.ISCA-RJAFS-2014-037.php

Bhat, K.M.; Priya, P.B.; Rugmini, P. 2001. Characterisation of juvenile wood in teak. Wood Sci Technol 34(6): 517-532. https://doi.org/10.1007/s002260000067

Bolza, E.; Kloot, N.H. 1963. The mechanical properties of 174 Australian timbers. Division of Forest Products Technological Paper No. 25. Commonwealth Scientific and Industrial Research Organization: Melbourne, Australia. http://nla.gov.au/nla.obj-540752254

Chowdhury, M.Q.; Ishiguri, F.; Hiraiwa, T.; Matsumoto, K.; Takashima, Y.; Iizuka, K.; Yokota, S.; Yoshizawa, N. 2012. Variation in anatomical properties and correlations with wood density and compressive strength in Casuarina equisetifolia growing in Bangladesh. Aust For 75(2): 95-99. https://doi.org/10.1080/00049158.2012.10676390

Duong, D.V. 2018. Study on within-tree variation in wood properties of Melia azedarach planted in northern Vietnam. Ph.D Thesis, Kyushu University, Japan. https://catalog.lib.kyushu-u.ac.jp

Duong, D.V.; Hasegawa, M.; Matsumura, J. 2019. The relations of fiber length, wood density, and compressive strength to ultrasonic wave velocity within stem of Melia azedarach. Journal of the Indian Academy of Wood Science 16(1): 1-8. https://doi.org/10.1007/s13196-018-0227-0

Duong, D.V.; Matsumura, J. 2018a. Transverse shrinkage variations within tree stems of Melia azedarach planted in northern Vietnam. J Wood Sci 64(6): 720-729. https://doi.org/10.1007/s10086-018-1756-2

Duong, D.V.; Matsumura, J. 2018b. Within-stem variations in mechanical properties of Melia azedarach planted in northern Vietnam. $J$ Wood Sci 64(4): 329-337. https://oi.org/10.1007/s10086-018-1725-9

Duong, D.V.; Missanjo, E.; Matsumura, J. 2017. Variation in intrinsic wood properties of Melia azedarach L. planted in northern Vietnam. $J$ Wood Sci 63(6): 560-567. https://doi.org/10.1007/s10086-017-1652-1

EI-Juhany, L.I. 2011. Evaluation of some wood quality measures of eight-year-old Melia azedarach trees. Turkish Journal of Agriculture and Forestry 35: 165-171. https://doi.org/10.3906/tar-0912-515

Gartner, B.L.; Lei, H.; Milota, M.R. 1997. Variation in the anatomy and specific gravity of wood within and between trees of red alder (Alnus rubra Bong.). Wood Fiber Sci 29(1): 10-20. https://wfs.swst.org/index.php/wfs/article/view/1877

Harrison, N.A.; Boa, E.; Carpio, M.L. 2003. Characterization of phytoplasmas detected in Chinaberry trees with symptoms of leaf yellowing and decline in Bolivia. Plant Pathology 52: 147-157. https://doi.org/10.1046/j.1365-3059.2003.00818.x

Honjo, K.; Furukawa, I.; Sahri, M.H. 2005. Radial variation of fiber length increment in Acacia mangium. IAWA J 26(3): 339-352. https://doi.org/10.1163/22941932-90000119

Ifju, G. 1983. Quantitative wood anatomy: certain geometrical-statistical relationships. Wood Fiber Sci 15(4): 326-337. https://wfs.swst.org/index.php/wfs/article/view/1498

Ishiguri, F.; Hiraiwa, T.; Iizuka, K.; Yokota, S.; Priadi, D.; Sumiasri, N.; Yoshizawa, N. 2009. Radial variation of anatomical characteristics in Paraserianthes falcataria planted in Indonesia. IAWA J 30(3): $343-$ 352. https://doi.org/10.1163/22941932-90000223

Ishiguri, F.; Takeuchi, M.; Makino, K.; Wahyudi, I.; Takashima, Y.; Iizuka, K.; Yokota, S.; Yoshizawa, N. 2012. Cell morphology and wood properties of Shorea acuminatissima planted in Indonesia. IAWA J 33(1): 25-38. https://doi.org/10.1163/22941932-90000077 
Kitin, P.; Funada, R.; Sano, Y.; Beeckman, H.; Ohtani, J. 1999. Variations in the lengths of fusiform cambial cells and vessel elements in Kalopanax pictus. Annals of Botany 84(5): 621-632. https://doi.org/10.1006/anbo.1999.0957

Lei, H.; Milota, M.R.; Gartner, B.L. 1996. Between- and within-tree variation in the anatomy and specific gravity of wood in Oregon white oak (Quercus garryana Dougl.). IAWA J 17(4): 445-461. https://doi.org/10.1163/22941932-90000642

Leles, P.S.D.S.; Machado, T.F.F.; Alonso, J.M.; de Andrade, A.M.; da Silva, L.L. 2014. Growth and biomass of Melia azedarach L. at different spacings and technological characteristics of wood for charcoal production. Floresta e Ambiente 21(2): 214-223. http://dx.doi.org/10.4322/floram.2014.020

Lev-Yadun, S.; Aloni, R. 1993. Effect of wounding on the relations between vascular rays and vessels in Melia azedarach L. New Phytologist 124: 339-344. https://doi.org/10.1111/j.1469-8137.1993.tb03824.x

Matsumura, J.; Inoue, M.; Yokoo, K.; Oda, K. 2006. Cultivation and utilization of Japanese fast growing trees with high capability for carbon stock I: potential of Melia azedarach. Mokuzai Gakkaishi 52(2): 77 82. https://doi.org/10.2488/jwrs.52.77

Miranda, I.; Almeida, M.H.; Pereira, H. 2001. Influence of provenance, subspecies and site on wood density in Eucalyptus globulus labill. Wood Fiber Sci 33(1): 9-15. https://wfs.swst.org/index.php/wfs/article/ view/66

Nasser, N.A. 2008. Effects of sewage effluent irrigation on the chemical components and mechanical properties of Melia azedarach L wood. Journal of Agriculture and Environment Sciences 7(3): 138-166. http://www.damanhour.edu.eg/pdf/agrfac/Root1/Vol7_3_6.pdf

Nasser, R.; Al-Meffarrej, H.; Abdel-Aal, M.; Hegazy, S. 2010. Chemical and mechanical properties of Melia azedarach mature wood as affected by primary treated sewage-effluent irrigation. American-Eurasian Journal of Agriculture and Environmental Sciences 7(6): 697-704. https://www.idosi.org/aejaes/jaes7(6)/14.pdf

National Institute of Heath. 2012. ImageJ software. Version 1.44. Bethesda Maryland, USA. https://imagej.nih.gov/ij/

Osei, A.K.; Kimaro, A.A.; Peak, D.; Gillespie, A.W.; Van Rees, K.C.J. 2018. Soil carbon stocks in planted woodlots and Ngitili systems in Shinyanga, Tanzania. Agroforestry Systems 92(2): 251-262. https://doi.org/10.1007/s10457-016-0028-7

Palakit, K.; Siripatanadilok, S.; Lumyai, P.; Duangsathaporn, K. 2018. Leaf phenology and wood formation of white cedar trees (Melia azedarach L.) and their responses to climate variability. Songklanakarin Journal of Science and Technology 40(1): 61-68. https://rdo.psu.ac.th/sjstweb/journal/40-1/40-1-7.pdf

Panshin, A.J.; de Zeeuw, C. 1980. Textbook of wood technology: Structure, Identification, Properties, and Uses of the Commercial Woods of the United States and Canada. McGraw-Hill Book Company: New York, USA.

R Core Team. 2016. R: A language and environment for statistical computing: Version 3.3.2. R Foundation for Statistical Computing, Vienna, Austria. https://www.R-project.org

Saravanan, V.; Parthiban, K.T.; Sekar, I.; Kumar, P.; Vennila, S. 2013. Radial variations in anatomical properties of Melia dubia cav. at five different ages. Academic Journals 8(45): 2208-2217. https://academicjournals.org/journal/SRE/article-abstract/5B877B542287

Savidge, R.A. 2003. Tree growth and wood quality. Chapter 1. In: Barnett, J.R.; Jeronimidis, G. (eds.). Wood quality and its biological basis. Blackwell Scientific: Oxford, UK.

Trianoski, R.; Iwakiri, S.; Matos, J.L.M. 2011. Potential use of planted fast-growing species for production of particleboard. J Trop For Sci 23(3): 311-317. https://www.jstor.org/stable/23616976

Tsuchiya, R.; Furukawa, I. 2009a. Radial variation in the size of axial elements in relation to stem incre- 
ment in Quercus serrata. IAWA J 30(1): 15-26. https://doi.org/10.1163/22941932-90000199

Tsuchiya, R.; Furukawa, I. 2009b. Radial variation of vessel lumen diameter in relation to stem increment in 30 hardwood species. IAWA J 30(3): 331-342. https://doi.org/10.1163/22941932-90000222

Venson, I.; Guzman, J.A.S.; Talavera, F.J.F.; Richter, H.G. 2008. Biological, physical and mechanical wood properties of Paraiso (Melia azedarach) from a roadside planting at Huaxtla, Jalisco, Mexico. J Trop For Sci 20(1): 38-47. https://www.jstor.org/stable/23616486

Walker, J.C.F. 2006. Primary wood processing: principles and practice. 2nd edition Springer: Dordrecht, Netherlands.

Zhang, S.Y.; Zhong, Y. 1992. Structure-property relationship of wood in East-Liaoning oak. Wood Sci Technol 26: 139-149. https://doi.org/10.1007/BF00194469 